\title{
Contesting and reshaping learning spaces: Students' activism in South Africa
}

\begin{abstract}
Zusammenfassung
Universitäten in Südafrika sind ein Mikrokosmos der Gesellschaft und bieten damit vielfach Anlass für Kritik. Im Jahr 2015 entstand die Studierendenbewegung Rhodes Must Fall, welche Dekolonialisierung forderte. Die soziale Bewegung wurde zu einer der wichtigsten sozialen Bewegungen in Post-Apartheit Südafrika. Während in der Studierendenbewegung die Universität der Grund zur Formation von Protest war, schufen Studierende im Rahmen der Universität einen Raum für transformatives Lernen. Der Artikel untersucht den ambivalenten Raum der Universität: auf der einen Seite als „Zielpunkt der Kritik“ und als Experimentier- und Reflexionsort über die Gesellschaft und gesellschaftlichen Wandel. Auf der anderen Seite ist die Universität ein Ort, an welchem kollektive Lernprozesse entstehen, welche alternatives Wissen kreierten, beispielsweise über Dekolonialisierung, und damit über Diskriminierung, Rassismus und Marginalisierung.
\end{abstract}

Schlüsselworte: Transformatives Lernen, Dekolonialisierung, Besetzung, Studierendenbewegung, Südafrika

\begin{abstract}
Universities in South Africa are a microcosm of society and thus offer grounds for criticism. In 2015, the Rhodes Must Fall student movement emerged, which demanded decolonization. This movement became one of the most important social movements in post-apartheid South Africa. While the student movement was formed to protest against the university, students created a space for transformative learning within the frame of the university. This article examines the ambivalence of the university: on the one hand, as a target of criticism and as a space for experimentation and reflection on society and societal change; and, on the other hand, as a space for emerging collective processes of transformative learning which created alternative knowledge, for instance in respect of decolonization and thus also discrimination, racism and marginalization.
\end{abstract}

Keywords: Transformative Learning, Decolonization, Occupation, Students' Movement, South Africa

\begin{abstract}
Introduction
Educational institutions such as universities can be a microcosm of society in that social problems are reflected, and different contingents of knowledge, for instance diverse kinds of disciplinary or epistemic knowledge, are in conflict with each other. Social movements, especially student protests, are crucial because they point to this problem and offer solutions involving ideas for an alternative university and/or society. In so doing, social movements manifest themselves as a learning space. The student protests in South Africa are no exception; they emerged in 2015, when students began to criticize the structural violence at universities in South Africa, including increasing tuition fees, discrimination and racism, a Westernoriented curriculum, and a cultural heritage, which values the colonial past. These different struggles have been summarized under the notion "decolonization" (Daniel, 2021a, b). With the slogans "\#Rhodes Must Fall" and "\#Fees Must Fall" students addressed the issue of increasing tuition fees and the structural violence behind it (Jansen, 2017, p. 40f.). Poor students and students belonging to the "missing middle class"1 , who are predominantly black', became increasingly excluded. The movement grew continuously to become a nationwide movement. These developments culminated in one of the most important social movements in post-apartheid South Africa ${ }^{3}$. It contributed to the political decision in 2017 that ensured the inclusion of students from poor households by offering free education. ${ }^{4}$

Student protests in South Africa, however, not only demand a radical break with the present system, but also create spaces for alternative imaginaries and for learning (Daniel, 2021b). The notion of decolonization shapes imagination and learning. In placing decolonization at the core of the movement, the students draw on decolonization movements in Africa, as well as American liberation movements or the anti-apartheid movement in South Africa. Both the practice of these movements and related theories are the starting point for the students' learning processes. They created an alternative learning space in order to interrupt everyday university teaching and acquire new knowledge through collective transformative learning. Here, the question arises under what conditions and
\end{abstract}


in what way did transformative learning shape student protests? In order to address this question, I will base my arguments on an empirical study which I conducted between 2016 and 2018 for the research project "Aspiring to alternative futures: Lived utopia in South Africa". 5 I conducted more than 80 biographical and semi-structured interviews and used ethnographic methods such as participant observation. In this article, I consider 15 biographical interviews with students and 13 guided interviews with academics and civil society actors. The uprisings at the universities differed with regard to their size and their demands (Booysen et al., 2016; Chikane, 2018; Langa, 2017; Nyamnjoh 2016); consequently, I will focus on the student protests at the University of Cape Town (UCT). Due to the students' demand for self-representation, sufficient space will be given to self-documentations and the interview narratives of students.

The article is structured in four parts: First, I will embed the university uprising in the academic debate on learning in social movement studies (section 2). Second, I will introduce the UCT as a site of protests and unpack the students' critiques (section 3). Third, I will analyze the concept of learning and the dimensions of transformative learning (section 4). Fourth, I will summarize the findings and show how these student protests inspired other activisms worldwide.

\section{Learning from the perspective of social movement studies}

Educational and social movement theory have been developed independently of each other, although there are studies, which combine the different perspectives (Hall et al., 2011; Scandrett et al., 2010; Miethe \& Roth, 2016). Most social movement studies on learning emerged after the so-called "cultural turn" (Kluttz \& Walter, 2018, p. 92). In these studies, the curriculum and educational institutions have been analyzed as targets of social movements. Other studies highlight how social movements stimulate learning processes, in the frame of formalized education or as informalized learning, on an individual or a collective basis, or even in social movement schools which offer to teach skills in organizing and protest mobilization (Hall et al., 2011; Miethe \& Roth, 2016; Kluttz \& Walter, 2018; Zielińska, 2011).

Learning may occur unintentionally, it may be encouraged and focused, or it may be structured as in social movement schools. Learning means the acquisition of existing knowledge or the development of counter-hegemonic knowledge (della Porta \& Pavan, 2017; Isaak et al., 2020; Kluttz \& Walter, 2018; Scandrett et al., 2010; Sisco et al., 2019). Irrespective of the learning content, it usually contributes to the strategic direction of the movement. For instance, key competencies, such as the ability to organize, discussion and argumentation skills, or sponsoring and management skills, are acquired in order to train people for effective protest organization and mobilization (Scandrett et al., 2010, p. 161). In addition, learning fosters collective identity through a shared understanding and knowledge of discontentment, which creates activism and shared demands (Kigore, 1999; Miethe \& Roth, 2016). Thus, social movements draw attention to problems, which are not recognized as such by society, or are not taken sufficiently seriously. They change public perceptions of the problem and contribute to spreading feelings of discontentment in society. Against this backdrop, I will approach student activism from two perspectives: First, I will show that education itself gives rise to the formation of protests (section 3). Second, I will investigate students' transformative learning (section 4). Following this understanding of transformative learning, I will investigate in which spaces and under which conditions transformative learning takes place during student protests, and discuss processes of transformative (collective) learning. Collective learning refers to aspects of learning in which student engage in mutual exchange and develop a shaped meaning (Kigore, 1999).

\section{University of Cape Town as a site of student protests}

UCT is the oldest and at the same time the leading institution of higher education in South Africa. Founded in the year 1829, as a high school for boys, it grew continuously and became a university shortly before 1900 . Today UCT is the top-rated university in Africa (World University Rankings, 2021). Research and teaching at UCT is regarded as ground-breaking and innovative. UCT describes itself as, "an inclusive and engaged research-intensive African university that inspires creativity through outstanding achievements in learning, discovery and citizenship; enhancing the lives of its students and staff, advancing a more equitable and sustainable social order and influencing the global higher education landscape" (UCT Homepage, 2021a).

With 29,000 students and 5,000 academic staff members, UCT is amongst the biggest universities. While UCT has a tradition of academic excellence, a look at history shows that not all South Africans have benefited from it, since for a long time black students and academic staff were excluded. Although the university admitted its first black students in the 1920s, the number remained low, particularly under the racist regime of apartheid. After the end of apartheid in 1994 and with reference to the "multi-cultural rainbow nation", the universities opened up to blacks. Although their number grew, income, gender and race still determines access to university. Although black citizens are the majority in South Africa, they remain underrepresented at UCT. While at most South African universities black students were in the the majority $(73.7 \%)$ in 2018 (DHET, 2018), the situation at UTC is different. In the year 2014 white students accounted for $35.8 \%$, blacks for $29.7 \%$, Coloureds for $15.9 \%$ and Indians for $8.1 \%$ (while $12.9 \%$ don't know in which category they belong) (Ndelu, 2017). Although UCT strives to address past and present injustices (UCT Homepage, 2021b), they still exist.

The students' protests have addressed the persistence of a culture, which is dominated by whites, a Western-oriented curriculum, discrimination and racism: the continuity of the past in the present and the structural prolongation of apartheid in the memory culture is a point of critique. From the perspective of students, looking at statues such as that of Cecil Rhodes ${ }^{6}$, is a form of "encountering history in the present" and reviving collective trauma (Interview student, 23.03.2017). This is astonishing insofar as this generation of students has been de- 
scribed as "born free", born in the post-apartheid era, and benefited most from the new democracy (Lewis \& Hendricks, 2017 , p. 9). From the students' perspective, the vulnerability of being black still exists. Therefore, they protested against a heritage culture, which values the colonial past, and a university in which they feel alienated. From the student's perspective, a welcoming university culture requires a curriculum, which is not predominantly oriented towards Western knowledge and pays sufficient attention to the history and culture of the black majority or to social needs (Cornell \& Kessi, 2017; Kessi \& Cornell, 2015). A student complained: "The West is always the starting point from which we articulate ourselves" (Interview student, 23.03.2017).

As a result, students felt that the university is an "unhomely, unwelcoming and exclusionary space" (Interview student, 28.02.2017), which went along with emotions such as alienation, isolation, inferiority, shame or anger. While some students expressed their feelings loudly, and used the spaces offered by the movement to do so, others were overwhelmed by the alienating university and their feelings of shame and inferiority. One student narrated: "Like I shut down, I become completely silent, I don't know how to interact" (Interview student, 13.09.2018). The alienating university culture also includes racism; many students complained about "macroaggression that happens around language, around professionalism, around who knows, who the knower is" (Interview student, 13.09.2018). There is also a prevalence of negative stereotypes in respect of black students at the university, such as that black people are lazy or unintelligent (Cornell \& Kessi, 2017, p. 5).

The students realized that, twenty years after the end of apartheid, the government had failed to keep the promise of a multicultural rainbow nation (Chikane, 2018; Turner, 2019). One student explained: "I think a kind of my illusion of a non-racial society is broken" (Interview student, 11.04.2017). ${ }^{7}$ All these critiques were summarized in the demand for "decolonization" (Daniel, 2021a). Decolonization was used with reference to decolonial movements that have existed in the African context since the 1950 s, the black power movements in the US, or the anti-apartheid struggles in South Africa, as well as the liberation literature, for instance of Franz Fanon (1963, 1967) or Steve Biko (1978).

Thus, students questioned the "elitist identity" of UCT (Interview student, 23.03.2017), but expected that UCT should take the lead in decolonizing the university (Interview student, 07.09.2018).

In order to achieve their aim, students used manifold tactics, including marches, demonstrations, shutdowns, performances, or occupations. They established counter-hegemonic spaces in which experimentation and learning enacted the imaginary of decolonization (Daniel, 2021b). In particular, the occupation of the Bremner Building offered a learning space. We can thus say that students' protests took place in a learning environment; they contested the curriculum and university culture, and created a counter-place for transformative learning.

\section{Rhodes Must Fall and transformative learning}

Transformative learning was developed by Jack Mezirow (1990) and means gaining a deeper self-awareness, more perspectives, and experiencing a deep shift in worldview, through critical reflection. According to Thomsen (2019) transformative learning consists of transformation of the self and one's relationship with the world. Kluttz \& Walter (2018) distinguish three levels (micro, meso and macro) ${ }^{9}$ of transformative learning. The focus of this article is on the meso-level: the activists transform their knowledge in relation to others and modify their previous position (Kluttz \& Walter, 2018, p. 99). Learning on the meso-level fosters collective identity formation, as people learn together. According to Kigore (1999, p. 191), individualized learning theories do not adequately explain collective learning and learning in the context of group dynamics as in social movements. ${ }^{10}$

\section{Rhodes Must Fall as learning space}

On March 20, 2015 students at UCT occupied the administrative building and maintained the occupation for some weeks. Right at the beginning, students renamed the administrative building Azania house. The Azania occupation was meant to provide a space in which a decolonial imaginary could be developed (Daniel, 2021b), as one student explained, "In those occupations, there was much deeper conversation about how we imagine our society. [...] We just started and notions of decoloniality came into the picture. That we are not here for transformation, we are here for decolonization. Because if societal disease is colonial the only remedy should, therefore, be decolonial" (Interview student, 23.03.2017).

The occupation offered a space for exchange, for the development of imaginaries, and for learning from each other. Flat organizational structures were intended to ensure that a broad diversity of students could be integrated in the learning processes. However, learning encountered limitations due to conflicts amongst students in respect of gender, class, or concerning the Students' Representative Council (Daniel, 2021a). Beyond this, language barriers hindered learning, as one student commented (Interview student, 16.09.2018). In addition, learning took place in a temporally limited space: it was interrupted by the forceful eviction of the students by the private security agents of the university. Thus, the learning space was fragile.

\section{Transformative learning}

While the Azania occupation offered opportunities to acquire skills in movement organization or mobilization (Interview student, 29.09.2017), the focus of collective learning was to reflect on decolonization, and thus on the realization and linguistic expression of experienced discrimination and racism. This form of learning was not about a clear-cut body of knowledge, but rather about acquiring knowledge in order to understand the felt discontent, and thus create meaning for one's own actions and activism. The students learned how to understand their disorientation in the world, and to express their emotions by listening to each other. A student described 
what she learned during the occupation: "I think it was a huge turning point (...) there was a language. (...) I think it is very important to be able to put words to something and be able to explain what you are feeling and to explain what you want" (Interview student, 29.08.2018).

Gaining an awareness of one's situation, and the language to express one's experiences, includes unlearning and critical reflection on one's existing awareness and knowledge, which the Kenyan postcolonial writer Ngugi wa Thiongo has described as "decolonizing the mind" (Interview student, 28.02.2017).

Unlearning in the sense of critical reflection on existing knowledge occurred through readings: students acquired a knowledge of decolonial theory, critical race theory, feminist and queer theory, and political philosophies such as Pan-Africanism. ${ }^{11}$ The students hosted lectures, reading groups or discussions (Interview academic, 20.08.2018). Even some academics contributed to the acquisition of "alternative" knowledge which was not taught at the university, and which led to critical reflection. The variety of readings, talks and discussions on decolonization led to collective learning, as the main aim was to learn from each other. A student described how she was inspired by another student: "I remember one guy got up, and he talked about Steve Biko and I remember thinking, I need to read the book (...) and that weekend I stayed at home, I read the book and I was crying because what Steve Biko was talking about, he was talking to me about the things that I experienced" (Interview student, 07.09.2018).

Students not only assisted each other in the reading, but listened to each other's experiences. Thus, students learned about the life of other students. In this transformative learning process, the diversity of students was a benefit: they had different class backgrounds, genders and sexes, and they grew up differently, but they shared experiences of suffering, discrimination and racism. A male student explains how he learned from the experiences of women and queer activists, and consequently changed his mind-set: "We'll be talking about (...) the experiences of different people in the movement, (...) how my experiences as an African male heterosexual are different from those of someone who is female and heterosexual, and how the movement itself accommodating of certain people and not of maybe queer people (...). And we'll be speaking about gender issues and about sexuality and just educating each other. So, it becomes a space of learning from each other" (Interview student, 28.09.2018).

Through this process of collective transformative learning, students understood their discontentment, and developed a language to express and recreate their relation to themselves and to the world through the lens of critical decolonial reflection on the university and society. This process helped people to identify themselves as black (Interview student, 11.04.2017), but transformative learning also paved the way to developing togetherness. A student described interactions during the occupation, "It becomes a space for community; we eat together, we sing, we dance, we watch documentaries and we debate about them afterwards, we speak about books. (...) It's a space for learning" (Interview student, 28.09.2018).

Thus, this environment fostered transformative learning: it shaped knowledge, perceptions and meanings, may have changed attitudes, and had an impact on belonging and identity. Learning also contributed to the development of a shared position and to collective identity (Kigore, 1999). Through learning the boundaries of the movement became clear, too.

\section{Conclusion}

"I really felt like (...) I got a better education in 18 months of an activists' space (...) than I got from university, at the best university of the continent, and I think that's something to reflect on" (Interview student, 28.09.2018). The occupation created a learning space in which collective transformative learning took place. The experience of this learning is contrasted with the educational experience at UCT, but is actually more consistent with the goals of the university. Because the university did not offer the "right knowledge" from the students' perspective, students created a counter-hegemonic space. Although the occupiers were violently evicted, students managed to institutionalize their learning, for instance with the Decolonial School. The Decolonial School, organized by students and recognized and hosted by UTC, became a regular offer at UCT, aimed at establishing a forum to think about education and to establish a space for alternative education (Interview student, 13.09.2018).

This student uprising inspired many movements, as the "must fall" notion has been interpreted as a need to break with the present and initiate radical change. Even abroad, the notion of "must fall" has encouraged many activists, and social movements have emerged. Consequently, the learning space of RMF has expanded transnationally. For instance, in Senegal, young people demonstrated against the statue of Louis Faidherbe, a French soldier, claiming that the statue is a continuation of the colonial past in the present (Ndiaye, 2020). Students in Oxford used the slogan for their demand to change the Eurocentric curriculum (Rhodes Must Fall Oxford, 2018). In the Sudanese revolution, the term was used to call attention to the need for radical change and thus a break with the Omar Basir regime (Bishai \& Elshami, 2019). The "must fall" movements are also closely related to Black Lives Matter (Harris, 2018). All these movements reveal the importance of informal learning spaces dismantling structures of oppression which constitute the continuation of an undesired past. While the learning process at UCT had its expression in the occupation of Azania house, RMF also stimulated a wider learning process, which centers around discrimination, racism or the curriculum and can stimulate (re)thinking education or educational concepts for the futures we wish to live in. Informal learning in social movements, can thus be an essential complement of formal education.

\section{Notes}

1 Particularly those students who belong to the increasing middle class tend to be financially excluded. Students who do not qualify for the National Student Financial Aid Scheme because their parents earn too much, but who cannot afford the fees or the costs of living and other expenses, belong to the missing middle class (Jansen, 2017, p. 33)

2 Black and white are used as socially and politically constructed categories of discrimination and racism (for a debate on the use and meaning of this concept, see Vally \& Motala, 2018). 
3 For an overview of the history of activism in South Africa, see Ballard et al., 2006; Duncan, 2016; Robins, 2008.

4 For literature on the student protests, see Booysen, 2016, Platzky Miller, 2019 or Ngcaweni \& Ngcawni, 2018

5 As part of this study, I also investigated activism of the housing movement Reclaim the City and environmental activism of the Green Camp Gallery Project and Oude Molen Eco Village. For further research from this project, see Daniel 2020, 2021a, b.

6 Students complain that the Rhodes statue symbolizes the imperial, exploitative system of colonialism and the exploitation of blacks.

7 Other demands of the students referred to intersectionality (Daniel, 2021a, c), and highlighted structural discrimination which has been expressed through the outsourcing campaign or demands for widespread political transformation (Nieftagodien, 2016).

8 Students across the country attempted to occupy buildings (Duncan \& Frassinelli, 2015; Manzini, 2017).

9 The micro-level refers to acquiring individual skills and knowledge, for instance on how to organize a protest or how to mobilize people. The macro-level investigates how learning interacts with the wider societal context in which the movement operates.

10 It is not always clear how to distinguish individual from collective learning. I talk about collective learning here, keeping in mind that individual learning and experiences differ and may be in contrast to collective learning.

11 Students also addressed UCT's history of racism, apartheid and the anti-apartheid struggles, as well as the experiences of the US Black Power Movement.

\section{References}

Ballard, R., Habib, A. \& Valodia, I. (2006). Voices of Protest. Social Movements in Post-Apartheid South Africa. Scottsville: University of KwaZulu-Natal Press.

Biko, S. (1979). Black Consciousness in South Africa. New York: Vintage Books.

Bishai, L. \& Azaz, E. (2019). "We are all Darfur!" - Sudan's Unity Protests Stand a Real Chance. Time for the West to Step Up. Zugriff am 02.04.2021 http://arabcenterdc.org/policy_analyses/we-are-all-darfur-sudans-unity-protests-stand-a-realchance-time-for-the-west-to-step-up/

Booysen, S. (Hrsg.). (2016). Fees Must Fall. Student Revolt, Decolonisation and Governance in South Africa. Johannesburg: Wits University. https://doi. org/10.18772/22016109858.6

Chikane, R. (2018). Breaking a Rainbow, building a Nation: The politics behind \#MustFall movements. Johannesburg: Picador Africa.

Cornell, J. \& Shose, K. (2017). Black students' experiences of transformation at a previously "white only" South African university: a photo voice study. Ethnic and Racial Studies, 40(11), 1882-1899. https://doi.org/10.1080/01419870.2016.1206 586

Council on Higher Education (2016). South African Higher Education Reviewed: Two Decades of Democracy. Pretoria: Council on Higher Education.

Daniel, A. (2019). Ambivalenzen des Forschens unter Bedingungen (post-)dekolonialer Debatten. Forschungsjournal Soziale Bewegungen, 31(1), 40-49. https://doi. org/10.1515/fjsb-2019-0005

Daniel, A. (2020). Brüchige Allianzen: LGBTQI* Aktivismen im Kontext der intersektionalen und dekolonialen Praxis der Studierendenbewegung der University of Cape Town. Peripherie, 40(1-2 ), 102-124. https://doi.org/10.3224/peripherie. v40i1-2.06

Daniel, A. (2021a). Dekolonial und intersektional? Ambivalenzen der Herrschaftskritik in der südafrikanischen Studierendenbewegung. In H. Maurer, H. Leinius \& J. Leinius (Hrsg.), Intersektionale und postkolonial-feministische Perspektiven als Mittel politikwissenschaftlicher Macht- und Herrschaftskritik (S. 203-224). Opladen: Barbara Budrich. https://doi.org/10.2307/j.ctv1c5cs1c.12

Daniel, A. (2021b). Must Decolonisation Occur on an Island? The Role of Occupation in Developing Future Visions within the \#Rhodes Must Fall Movement. In I. Turner, E. Woldegiorgis \& A. Brahima (Hrsg.), Indigenous Knowledges and Decolonisation in Higher Education: Current Discourses, Pertinence and Prospects (S. 193212). London: Routledge. https://doi.org/10.4324/9780429355288-10

Daniel, A. (2021c). Rhodes Must Fall: Different layers of intersectionality in students' protests in South Africa. Interfaces, 13(1), 12-37.

della Porta, D. \& Pavan, E. (2017). Repertoires of knowledge practices: Social movements in times of crisis. Qualitative Research in Organizations and Management 12(4), 297-314. https://doi.org/10.1108/QROM-01-2017-1483

Duncan, J. (2016). Protest Nation: The right to protest in South Africa. Scottsville: University of Kwazulu-Natal Press.

Fanon, F. (1963 / 2004). The Wretched of the Earth. New York: Grove.

Fanon, F. (1964 / 1996). Black Skin, White Masks. London: Pluto.
Godsell, G. \& Rekgotsofetse, C. (2016). The roots of revolution. In S. Booysen (Hrsg.), Fees Must Fall. Student Revolt, Decolonisation and Governance in South Africa (S. 54-73). Johannesburg: Wits University. https://doi.org/10.18772/22016 109858.7

Gwisai, M. (2017). "Zuma Must Fall" and the Left: Lessons from Zimbabwe. Zugriff am 02.04.2021 https://roape.net/2017/05/25/zuma-must-fall-left-lessons-zimbabwe/

Hall, B. L., Clover, D. E., Crowther, J. \& Scandrett, E. (2011). Social movement learning: a contemporary re-examination. Studies in the Education of Adults, 43(2), 113-116. https://doi.org/10.1080/02660830.2011.11661607

Harris, D. (2018). Black Lives Matter. Minneapolis \& Minnesota: Core Library.

Isaac, L. W., Jacobs, A. \& McGrath, A. (2020). Social movement schools: sites for consciousness transformation, training, and prefigurative social development. Social Movement Studies, 19(2), 160-182. https://doi.org/10.1080/14742837.2019.1631 151

Jansen, J. (2017). As by Fire. The End of the South African University. Cape Town: Tafelberg.

Kilgore, D. W. (1999). Understanding learning in social movements: a theory of collective learning. International Journal of Lifelong Education, 18(3), 191-202. https://doi.org/10.1080/026013799293784

Kluttz, J. \& Walter, P. (2018). Conceptualizing Learning in the Climate Justice Movement.AdultEducation Quarterly, 68(2), 91-107.https://doi.org/10.1177/0741 713617751043

Langa, M. (Ed.), \#Hashtag. An analysis of the \#FeesMustFall Movement at South African universities. Johannesburg \& Cape Town: Centre for the Study of Violence and Reconciliation.

Lewis, D. \& Hendricks, C. M. (2017). Epistemic Ruptures in South African Standpoint Knowledge-Making: Academic Feminism and the\# FeesMustFall Movement. Gender Questions, 4(1), https://doi.org/10.25159/2412-8457/2920

Mezirow, J. (1990). Fostering critical reflection in adulthood: a guide to transformative and emancipatory learning. San Francisco: Jossey-Bass Publication.

Miethe, I. \& Roth, S. (2016). Bildung und soziale Bewegungen - eine konzeptionelle Einführung. Forschungsjournal Soziale Bewegungen, 29(4), 20-29. https://doi. org/10.1515/fjsb-2016-0262

Ndelu, S. (2017). Liberation is a Falsehood. Fallism at the University of Cape Town. In M. Langa (Hrsg.), \#Hashtag. An Analysis of the \#FeesMustFall Movement at South African Universities (S. 58-82). Johannesburg u. Cape Town: Centre for the Study of Violence and Reconciliation.

Ndiaye, K. (2020). In Senegal and France, Faidherbe Must Fall. Zugriff am 02.04.2021 https://roape.net/2020/07/07/in-senegal-and-france-faidherbe-must-fall/

Ngcaweni, W. \& Busani, N. (2018). We are no longer at ease. The struggles for \#Fees Must Fall. Cape Town: Janana Media.

Nieftagodien, N. (2016). Outsourcing is falling but a luta continua. Amandla, 9, (43-44), 10-11.

Nohl, A. M. (2015). Bildung und transformative learning: Eine Parallelaktion mit Konvergenzpotentialen. In D. Verständig, J. Holze \& R. Biermann (Hrsg.), Von der Bildung zur Medienbildung (S. 163-177). Wiesbaden: Springer VS. https://doi org/10.1007/978-3-658-10007-0_9

Nyamnjoh, F. B. (2016). \#RhodesMustFall. Nibbling at Resilient Colonialism in South Africa. Mankon \& Bamenda: Langaa Research \& Publishing CIG. https://doi.org/10.2307/j.ctvmd84n8

Platzky Miller, J. (2019). Politics, Education and the Imagination in South African and Brazilian student-led mobilisations (2015-16). Dissertation, University of Cambridge.

Rhodes Must Fall Oxford. Chantiluke, J., B. Kwoba \& A. Nkopo (Hrsg.). (2018). Rhodes Must Fall. The Struggle to Decolonise the Racist Heart of Empire. London: Zed Books. https://doi.org/10.5040/9781350222380

Robins, S. L. (2008). From Revolution to Rights in South Africa: Social Movements, NGOs and Popular Politics After Apartheid. Woodbridge: Boydell \& Brewer.

Scandrett, E., Crowther, J., Hemmi, A., Mukherjee, S., Shah, D. \& Sen, T. (2010). Theorising education and learning in social movements: environmental justice campaigns in Scotland and India. Studies in the Education of Adults, 42(2), 124-140. https://doi.org/10.1080/02660830.2010.11661593

Shose, K. \& Cornell, J. (2015). Coming to UCT. Black students, transformation and discourses of race. Journal of Student Affairs in Africa, 3(2), 1-16. https://doi. org/10.14426/jsaa.v3i2.132

Sisco, S., Valesano, M. \& Collins, J. C. (2019). Social Movement Learning and Human Resource Development: An Agenda for a Radical Future. Advances in Developing Human Resources, 21(2), 175-192. https://doi.org/10.1177/152342231982 7917

Thomsen, S. (2019). Bildung in Protestbewegungen: Empirische Phasentypiken und Normativitäts- und Bildungstheoretische Reflexionen. Wiesbaden: Springer VS. https://doi.org/10.1007/978-3-658-24199-5 
Turner, I. (2019). Axing the Rainbow. Modern Africa, 7(1), 81-110. https://doi. org/10.26806/modafr.v7i1.244

University of Cape Town (2021a). Homepage. Zugriff am 02.08.2021 https://www. uct.ac.za

University of Cape Town (2021b). History Introduction. Zugriff am 02.08.2021 https://www.uct.ac.za/main/about/history

Vally, S. \& Ever, M. (2018). Troubling "race" as a category of explanation in social science research and analysis. Southern African Review of Education, 24(1), 25-42.

World University Ranking (2021). About University of Cape Town. Zugriff am 02.08.2021 https://www.timeshighereducation.com/world-university-rankings/ university-cape-town

Xaba, W. (2017). Challenging Fanon. A Black Radical Feminist Perspective on violence and the Fees Must Fall Movement. Agenda, 31(3-4), 96-104. https://doi.or g/10.1080/10130950.2017.1392786

Zielińska, M., Kowzan, P. \& Prusinowska, M. (2011). Social Movement Learning: From Radical Imagination to Disempowerment? Studies in the Education of Adults, 43(2), 251-267. https://doi.org/10.1080/02660830.2011.11661616

\section{Dr. Antje Daniel}

ist Universitätsassistentin (post-doc) am Institut für Internationale Entwicklung der Universität Wien. Nach ihrer Promotion zu Frauenbewegungen in Kenia und Brasilien, welche sie an der Bayreuth International Graduate School of African Studies der Universität Bayreuth abgeschlossen hat, hatte sie mehrere Anstellungen an der Universität Bayreuth, der Akkon Hochschule und der Universität Wien. Die Forschungsschwerpunkte der Autorin liegen im Bereich der politischen Soziologie/Politikwissenschaften sowie der Protest- und Bewegungsforschung in Afrika, Latein Amerika und Europa. Derzeit beschäftigt sie sich mit Studierendenprotesten, Umweltaktivismus, Protesten für sozialen Wohnungsbau sowie mit den Corona-Protesten. Sie ist ebenso Co-Editorin des Africa Spectrums und des Journals für Entwicklungspolitik und betreut die Publikationsreihe des Nomos Verlags „Politik und Gesellschaft in Afrika“.

\section{UNSERE BUCHEMPFEHLUNG}

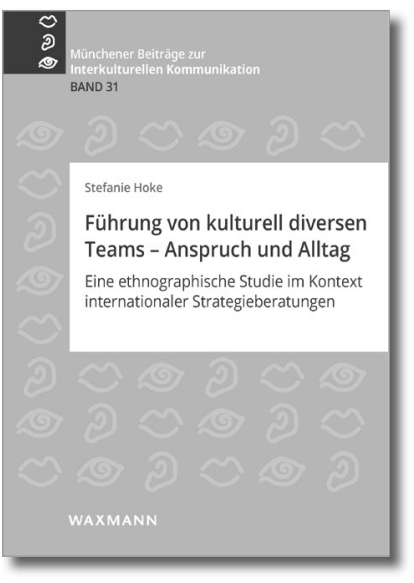

Münchener Beiträge zur Interkulturellen Kommunikation, Band 31, 2021, 290 Seiten, br., 37,90 €,

ISBN 978-3-8309-4387-7

E-Book: 33,99

ISBN 978-3-8309-9387-2

WAXMANN

www.waxmann.com
Stefanie Hoke

\section{Führung von kulturell diversen Teams - Anspruch und Alltag Eine ethnographische Studie im Kontext
internationaler Strategieberatungen}

Kulturelle Diversität stellt ein Idealbild einer modernen und offenen Organisation dar - auf sie ist man stolz, sie wird gefördert und beworben. Für Führungskräfte bedeutet die zunehmende kulturelle Diversität ihrer Teams allerdings auch eine Herausforderung, denn ihre Führungsrealität ist stärker geprägt durch das Organisieren von immer komplexer werdenden Situationen. Diese Zunahme an Komplexität und die gleichzeitig positive Bewerbung von Diversität als Mehrwert auf der Organisationsebene eröffnen ein Spannungsfeld, dessen Auflösung im Führungsalltag den Akteurinnen und Akteuren häufig selbst überlassen bleibt. Genau dieses Spannungsfeld nimmt die Autorin in diesem Band in den Fokus und analysiert mit einem ethnographischen Forschungsansatz die sozial konstruierte Wirklichkeit von Führungskräften in internationalen Strategieberatungen. 